Nevada

Environmental

Restoration

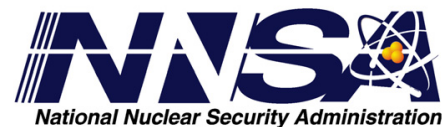

Project

\title{
Addendum to the Closure Report for Corrective Action Unit 271: \\ Areas 25, 26, and 27 Septic Systems Nevada Test Site, Nevada
}

Controlled Copy No::

Revision No.: 0

October 2008

Approved for public release; further dissemination unlimited.

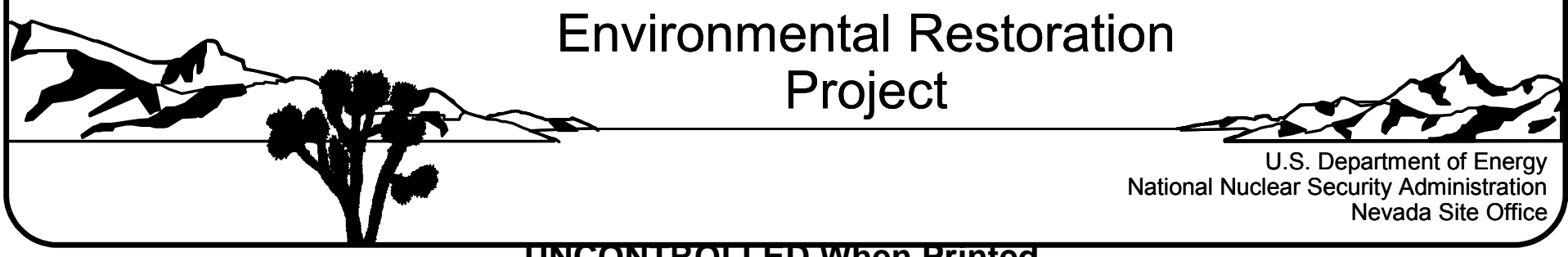


Available for public sale, in paper, from:

U.S. Department of Commerce

National Technical Information Service

5285 Port Royal Road

Springfield, VA 22161

Phone: 800.553 .6847

Fax: 703.605.6900

Email: orders@ntis.gov

Online ordering: http://www.ntis.gov/ordering.htm

Available electronically at $\underline{h t p: / / w w w . o s t i . g o v / b r i d g e ~}$

Available for a processing fee to U.S. Department of Energy and its contractors, in paper, from:

U.S. Department of Energy

Office of Scientific and Technical Information

P.O. Box 62

Oak Ridge, TN 37831-0062

Phone: 865.576 .8401

Fax: 865.576.5728

Email: reports@adonis.osti.gov

Reference herein to any specific commercial product, process, or service by trade name, trademark, manufacturer, or otherwise, does not necessarily constitute or imply its endorsement, recommendation, or favoring by the United States Government or any agency thereof or its contractors or subcontractors. 


\title{
ADDENDUM TO THE CLOSURE REPORT FOR CORRECTIVE ACTION UNIT 271: AREAS 25, 26, AND 27 SEPTIC SYSTEMS NEVADA TEST SITE, NEVADA
}

\author{
U.S. Department of Energy \\ National Nuclear Security Administration \\ Nevada Site Office \\ Las Vegas, Nevada
}

Controlled Copy No.:

Revision No.: 0

October 2008

Approved for public release; further dissemination unlimited. 


\section{Addendum to the Closure Report for Modification of the Use Restriction}

This document constitutes an addendum to the August 2004, Closure Report for Corrective Action Unit 271, Areas 25, 26, and 27 Septic Systems as described in the document Recommendations and Justifications for Modifications for Use Restrictions Established under the U.S. Department of Energy, National Nuclear Security Administration Nevada Site Office Federal Facility Agreement and Consent Order (UR Modification document) dated February 2008. The UR Modification document was approved by NDEP on February 26, 2008. The approval of the UR Modification document constituted approval of each of the recommended UR modifications. In conformance with the UR Modification document, this addendum consists of:

- This cover page that refers the reader to the UR Modification document for additional information

- The cover and signature pages of the UR Modification document

- The NDEP approval letter

- The corresponding section of the UR Modification document

This addendum provides the documentation justifying the modification of the UR for CAS 27-05-02, Leachfield. This UR was established as part of a Federal Facility Agreement and Consent Order (FFACO) corrective action and is based on the presence of contaminants at concentrations greater than the action levels established at the time of the initial investigation (FFACO, 1996; as amended August 2006).

Since this UR was established, practices and procedures relating to the implementation of risk-based corrective actions (RBCA) have changed. Therefore, this UR was re-evaluated against the current RBCA criteria as defined in the Industrial Sites Project Establishment of Final Action Levels (NNSA/NSO, 2006c). This re-evaluation consisted of comparing the original data (used to define the need for the UR) to risk-based final action levels (FALs) developed using the current Industrial Sites RBCA process.

The re-evaluation resulted in a recommendation to modify the UR to an administrative UR. Administrative URs differ from standard URs in that they do not require onsite postings (i.e., signs) or other physical barriers (e.g., fencing, monuments), and they do not require periodic inspections (see Section 6.2 of the Industrial Sites Project Establishment of Final Action Levels [NNSA/NSO, 2006c]). This Administrative UR was based on an "Occasional Use Area" future land use scenario that was used to calculate the FAL. The administrative UR will protect workers from an exposure exceeding that used in the calculation of the FAL (i.e., 400 total work hours). Any proposed activity within this use restricted area that would potentially cause an exposure exceeding this exposure limit would require approval from the Nevada Division of Environmental Protection (NDEP).

Requirements for inspecting and maintaining postings at this UR will be canceled, and the postings and signage at this site will be removed. Fencing and posting may be present at this site that are unrelated to the FFACO UR such as for radiological control purposes as required by the NV/YMP Radiological Control Manual (NNSA/NSO, 2004f). This modification will not affect or modify any non-FFACO requirements for fencing, posting, or monitoring at this site. 
Nevada

Environmental

Restoration

Project

Recommendations and Justifications for Modifications for Use Restrictions Established under the U.S. Department of Energy, National Nuclear Security Administration Nevada Site Office

Federal Facility Agreement and Consent Order

Controlled Copy No.:

Revision No.: 0

February 2008

Approved for public release; further dissemination unlimited.

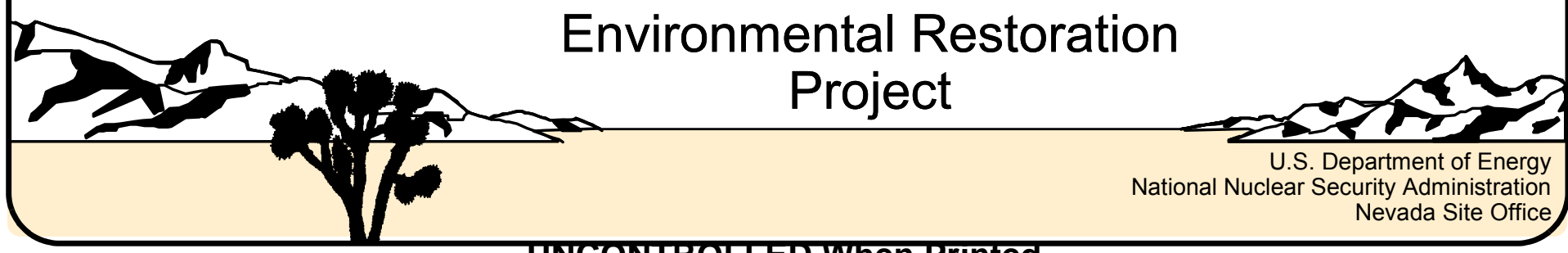


Recommendations and Justifications for Modifications for Use Restrictions Established under the U.S. Department of Energy, National Nuclear Security Administration Nevada Site Office Federal Facility Agreement and Consent Order

Approved by: /s/ Kevin J. Cabble

Date: $02 / 05 / 2008$

Kevin J. Cabble

Federal Sub-Project Director

Industrial Sites Sub-Project

Approved by:

/s/ John B. Jones

Date: $02 / 04 / 2008$

John B. Jones

Acting Federal Project Director

Environmental Restoration Project 
February 26, 2008

John B. Jones

Acting Federal Project Director

Environmental Restoration Project

National Nuclear Security Administration

Nevada Site Office

P. O. Box 98518

Las Vegas, NV 89193-8518

RE: Approval of Recommendations and Justifications for Modifications for Use Restrictions

Established under the U.S. Department of Energy, National Nuclear Security Administration, Nevada Site Office Federal Facility Agreement and Consent Order

Dear Mr. Jones:

The Nevada Division of Environmental Protection, Bureau of Federal Facilities (NDEP) staff has received and reviewed the February 2008 final report for Recommendations and Justifications for Modifications for Use Restrictions Established under the U.S. Department of Energy, National Nuclear Security Administration, Nevada Site Office. The NDEP approves the requested changes to the previously agreed upon use restrictions for those Corrective Action Sites (CASs) as described in the report.

Address any questions regarding this matter to either Ted Zaferatos at (702) 486-2850, ext. 234 , or me at (702) 486-2850, ext. 231.

Sincerely

\section{/s/ Tim Murphy}

\section{T.H. Murphy}

Chief

Bureau of Federal Facilities

$\mathrm{TZ}$

cc: $\quad$ E.F. DiSanza, WMP, NNSA/NSO

FFACO Group, PSG, NNSAINSO, Las Vegas, NV

David C. Loewer, DTRAVCXT1, M/S 645, Mercury, NV

W.R. Griffin, SNJV/DTRA, M/S 645, Mercury, NV

T.A. Thiele, NSTec, Las Vegas, NV

R.F. Boehlecke, SNJV, Las Vegas, NV

K. J. Cabble, ERP, NNSANSO, Las Vegas, NV

John Wong. Jeff MacDougall, Dennis Nicodemus, NDEP Las Vegas, NV 


\subsection{CAU 271, CAS 27-05-02 - Leachfield}

\subsection{CAS Description}

The septic system is located southwest of Building 5210 and west of Building 5200. The west side of the CAS 27-05-02 leachfield is bordered by a natural wash (i.e., arroyo). The septic system received effluent from restroom facilities including toilets, urinals, sinks, and floor drains inside Buildings 5210 and 5200. In addition, Building 5210 had a full kitchen with food preparation, dish washing, and cleanup operations. Building 5200 contained a service sink and an acid dip tank located beside a sink on a "solder bench." The septic system consisted of the influent lines from Buildings 5210 and 5200, a septic tank, a distribution structure, and a leachfield. The septic tank and distribution structure were removed as part of the corrective action. The remaining leachfield is approximately $80 \mathrm{ft}$ long by $24 \mathrm{ft}$ wide and consists of five 4-inch (in.), parallel orangeburg distribution lines. The lines are approximately $80 \mathrm{ft}$ long and spaced $6 \mathrm{ft}$ apart on center. The distribution lines are placed in 2-ft-wide trenches. A layer of approximately 18 in. of coarse gravel served as leachrock in each trench. The septic tank, manhole, and distribution box were removed (DOE/NV, 2001b).

\subsection{Current Use Restriction Description}

The future use of any land affected by this UR is restricted from any DOE or Air Force activity that may alter or modify the containment control as approved by the state and identified in the CAU CR or other CAU documentation unless appropriate concurrence is obtained in advance. The only remaining COCs associated with this CAS are confined to the leachfield. The UR was implemented for the leachfield to control inadvertent intrusion or exposure to the leachfield. Warning signs were installed at the four corners of the leachfield. An inspection will be performed annually and will consist of visual observations to verify that the proper signs are in place and readable, and the UR is maintained (NNSA/NSO, 2004a).

\subsection{Basis for Current Use Restriction}

Samples from this CAS were analyzed for VOCs, SVOCs, RCRA metals, TPH (DRO and GRO), and PCBs. The PALs were not exceeded in any of the soil samples from remaining materials (following remediation) except arsenic and PCBs.

Arsenic was detected above the PAL of $2.7 \mathrm{mg} / \mathrm{kg}$ in 50 percent of the samples analyzed. Arsenic was detected at concentrations up to $4.93 \mathrm{mg} / \mathrm{kg}$. Concentrations of arsenic are 
consistent in the leachfield soil and do not appear to represent locations of elevated radioactivity or evidence of a localized spill. Although arsenic concentrations in the soil exceed the PAL of $2.7 \mathrm{mg} / \mathrm{kg}$, these concentrations are believed to be within ambient conditions for CAS 27-05-02 and do not represent contamination. Therefore, arsenic is not considered to be a basis for this UR (NNSA/NSO, 2004d).

Elevated PCB concentrations were identified in the leachfield soil. Aroclor 1254 was detected at 7,600 micrograms per kilogram $(\mu \mathrm{g} / \mathrm{kg})$ in one sample, exceeding the $1,000 \mu \mathrm{g} / \mathrm{kg}$ PAL.

Aroclor 1248 was detected in concentrations exceeding the $1,000 \mu \mathrm{g} / \mathrm{kg}$ PAL, in 10 samples, at levels up to $22,000 \mu \mathrm{g} / \mathrm{kg}$. The highest concentrations were detected in surface soil samples (NNSA/NSO, 2004d).

Table 7-1 contains analytical results of all COCs at CAS 27-05-02 that are the basis for the current UR. The sample matrix for all samples is soil.

Table 7-1

Sample Results for COCs at CAS 27-05-02 Used To Establish Current Use Restriction

\begin{tabular}{|c|c|c|c|}
\hline \multirow{2}{*}{ Sample ID } & \multirow{2}{*}{$\begin{array}{c}\text { Depth } \\
\text { (ft bgs) }\end{array}$} & Aroclor 1248 & Aroclor 1254 \\
\hline & & $\begin{array}{c}\text { PAL } \\
1,000 \mu \mathrm{g} / \mathrm{kg}\end{array}$ & $\begin{array}{c}\text { PAL } \\
1,000 \mu \mathrm{g} / \mathrm{kg}\end{array}$ \\
\hline 271Q003 & $5.2-6.2$ & 1,000 & -- \\
\hline 271Q203 & $5.5-6$ & 5,300 & $7,600(\mathrm{~J})$ \\
\hline 271Q208 & $0-0.5$ & 19,000 & -- \\
\hline 271Q224 & $0-1$ & 22,000 & -- \\
\hline $271 Q 225$ & $2.5-3$ & 4,700 & - \\
\hline 271Q228 & $0-0.5$ & 8,400 & -- \\
\hline 271Q229 & $2.5-3$ & 9,400 & -- \\
\hline 271Q230 & $2.5-3$ & 1,500 & -- \\
\hline 271Q231 & $5.5-6$ & 2,800 & -- \\
\hline 271Q232 & $8.5-9$ & 5,800 & -- \\
\hline
\end{tabular}

bgs $=$ Below ground surface $\mathrm{ft}=$ Foot

$\mathrm{J}=$ Estimated value

ID = Identification

-- = No detects above action levels

PAL = Preliminary action level $\mu \mathrm{g} / \mathrm{kg}=$ Micrograms per kilogram 


\subsection{Basis for Use Restriction Modification}

The revised FALs for PCBs listed in Table 7-2 were established using the Tier 2-based FAL process presented in Section 2.2.2. These FALs were calculated using the Occasional Use Area site-specific exposure scenario. This scenario assumes that a worker will be exposed to the site contaminants for up to 400 total hours. This exposure scenario is for undeveloped sites, where there are no facilities, where an industrial worker would normally be assigned (NNSA/NSO, 2006c). Because CAS 27-05-02 is located in a remote area of the NTS (Area 27), no current or foreseeable future activities would cause any worker to be exposed to this site for a period of time exceeding that assumed in the Occasional Use Area site-specific scenario (i.e., 400 total hours). However, these undeveloped areas may be used for military type exercises where it is assumed that a worker could be exposed for a period of up to 80 hours per year for five years.

The UR modification would be to implement an administrative UR as described in Section 2.0. This administrative UR would restrict any activity that would result in any worker being within the UR boundary for a lifetime-duration of more than 400 total hours.

Table 7-2 presents the sample results that are the basis for the current UR and demonstrate that none exceed the revised FALs (based on an Occasional Use Area land-use scenario).

Table 7-2

Revised Final Action Levels for CAS 27-05-02 (Page 1 of 2)

\begin{tabular}{||c|c|c|c||}
\hline \multirow{2}{*}{ Sample ID } & \multirow{2}{*}{$\begin{array}{c}\text { Depth } \\
\text { (ft bgs) }\end{array}$} & $\begin{array}{c}\text { Aroclor 1248 } \\
\text { Revised FAL } \\
\mathbf{5 9 , 1 0 0} \boldsymbol{\mu g} / \mathbf{k g}\end{array}$ & $\begin{array}{c}\text { Aroclor 1254 } \\
\mathbf{4 9 , 1 0 0} \boldsymbol{\mu g} \mathbf{~} \mathbf{k g}\end{array}$ \\
\hline \hline $271 \mathrm{Q} 003$ & $5.2-6.2$ & 1,000 & -- \\
\hline $271 \mathrm{Q} 203$ & $5.5-6$ & 5,300 & $7,600(\mathrm{~J})$ \\
\hline $271 \mathrm{Q} 208$ & $0-0.5$ & 19,000 & -- \\
\hline $271 \mathrm{Q} 224$ & $0-1$ & 22,000 & -- \\
\hline $271 \mathrm{Q} 225$ & $2.5-3$ & 4,700 & -- \\
\hline $271 \mathrm{Q} 228$ & $0-0.5$ & 8,400 & -- \\
\hline $271 \mathrm{Q} 229$ & $2.5-3$ & 9,400 & -- \\
\hline $271 \mathrm{Q} 230$ & $2.5-3$ & 1,500 & -- \\
\hline $271 \mathrm{Q} 231$ & $5.5-6$ & 2,800 & -- \\
\hline
\end{tabular}


Table 7-2

Revised Final Action Levels for CAS 27-05-02

(Page 2 of 2)

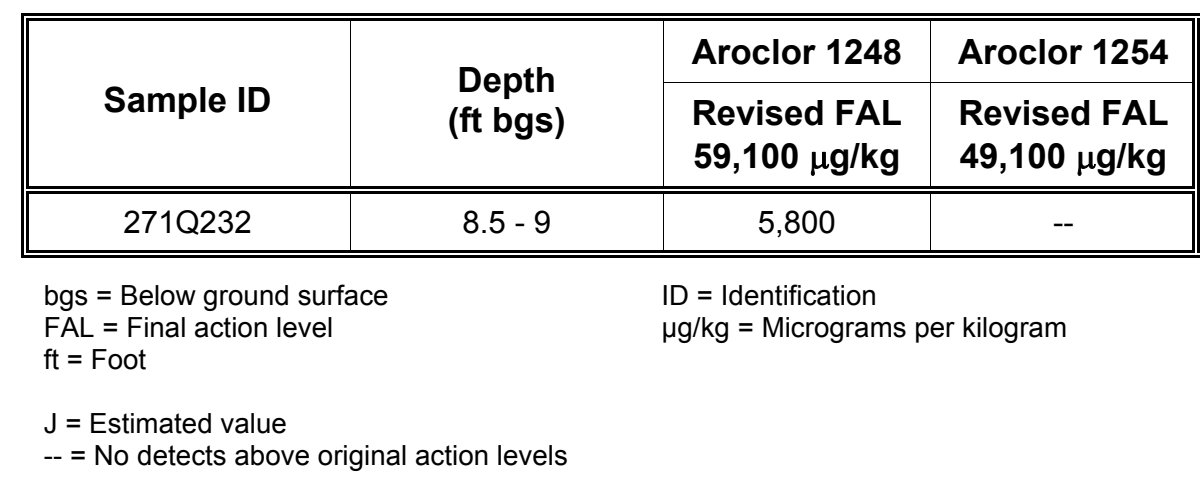

\subsection{Proposed Modification}

Implement an administrative UR as described in Section 2.0 restricting any activity that would result in any worker being within the UR boundary for a lifetime-duration of more than 400 total hours. Remove all associated fencing and postings and discontinue inspection and maintenance at this site. 


\section{References}

DOE/NV, see U.S. Department of Energy, Nevada Operations Office.

FFACO, see Federal Facility Agreement and Consent Order.

Federal Facility Agreement and Consent Order. 1996 (as amended). Agreed to by the State of Nevada; U.S. Department of Energy, Environmental Management; U.S. Department of Defense; and U.S. Department of Energy, Legacy Management.

NNSA/NSO, see U.S. Department of Energy, National Nuclear Security Administration Nevada Site Office.

NNSA/NV, see U.S. Department of Energy, National Nuclear Security Administration Nevada Operations Office.

U.S. Department of Energy, National Nuclear Security Administration Nevada Operations Office. 2001b. Corrective Action Decision Document/Closure Report for Corrective Action Unit 321: Area 22 Weather Station Fuel Storage, Nevada Test Site, Nevada, Rev. 1, DOE/NV--726. August. Las Vegas, NV.

U.S. Department of Energy, National Nuclear Security Administration Nevada Site Office. 2004f. NV/YMP Radiological Control Manual, DOE/NV--11718-079, Rev. 5. Prepared by Bechtel Nevada. Las Vegas, NV.

U.S. Department of Energy, National Nuclear Security Administration Nevada Site Office. 2006c. Industrial Sites Project Establishment of Final Action Levels, Rev. 0, DOE/NV--1107. Las Vegas, NV.

U.S. Department of Energy, National Nuclear Security Administration Nevada Site Office. 2004a. Closure Report for Corrective Action Unit 271: Areas 25, 26, and 27 Septic Systems, Nevada Test Site, Nevada, Rev. 0, DOE/NV--998. August. Las Vegas, NV.

U.S. Department of Energy, National Nuclear Security Administration Nevada Site Office. 2004d. Corrective Action Decision Document for Corrective Action Unit 271: Areas 25, 26, and 27 Septic Systems, Nevada Test Site, Nevada, Rev. 1, DOE/NV--838-REV.1. September. Las Vegas, NV. 


\title{
Library Distribution List
}

\author{
$\underline{\text { Copies }}$ \\ 1 (Uncontrolled, electronic copy) \\ U.S. Department of Energy \\ National Nuclear Security Administration \\ Nevada Site Office \\ Technical Library \\ P.O. Box 98518, M/S 505 \\ Las Vegas, NV 89193-8518 \\ U.S. Department of Energy \\ Office of Scientific and Technical Information \\ 1 (Uncontrolled, electronic copy) \\ P.O. Box 62 \\ Oak Ridge, TN 37831-0062 \\ Southern Nevada Public Reading Facility \\ 2 (Uncontrolled, electronic copies) \\ c/o Nuclear Testing Archive \\ P.O. Box 98521, M/S 400 \\ Las Vegas, NV 89193-8521 \\ Manager, Northern Nevada FFACO \\ 1 (Uncontrolled, electronic copy) \\ Public Reading Facility \\ c/o Nevada State Library \& Archives \\ 100 N Stewart Street \\ Carson City, NV 89701-4285
}

